\title{
Leaping Forward Period (1995 \\ to Present): Moving into Digital Mapping and Digital Cartography Era
}

\author{
Xuan Wu, Fanyu Qi, Guo Liu, Yuntao Shang, and Jie Meng
}

During the Ninth Five-Year Plan period, the Ministry of Geology and Mineral Resources deployed a pilot project for the construction of space database of 1:20 million. Since 2000, China Geological Survey has developed computer mapping systems in combination with regional geological survey. From 1999 to 2006, the China Geological Survey (CGS) completed a number of 1:250000 Regional geological maps using $3 \mathrm{~S}$ technology in the area of $152,000 \mathrm{~km}^{2}$ in Qinghai-Tibet Plateau and its adjacent areas, in accordance with the unified mapping technical standards. This is an epoch-making project, marking the full completion of the medium-scale regional geological survey of China's land. What Lu Xun has said, "There is no home-made precise geological map in its territory and its city of a non-civilized country" has been fully realized.

Computer-aided mapping not only changes the traditional geological mapping method, speeds up the mapping speed, reduces the labor intensity, and improves the quality of information transmission function and loading function of geological mapping, but also gives geologists sufficient time for comprehensive analysis and thinking and improves the understanding of regional geological development and tectonic evolution. With the continuous development and improvement of computer mapping and 3S technology, China has possessed a large number of precise geological maps and databases, such as geological, mineral, hydrological, environmental, geophysical, and geochemical exploration maps and databases of different scales, nationwide and regional. China's geological mapping has entered into the

\footnotetext{
X. Wu $(\bowtie) \cdot$ F. Qi $\cdot$ Y. Shang $\cdot$ J. Meng

Development and Research Center of China Geological Survey

(National Geological Archives of China),

Xicheng District, Beijing, P.R. China

e-mail:wxuan@mail.cgs.gov.cn

G. Liu

National Geological Library of China/Geoscience Documentation Center, China Geological Survey,

Haidian District, P.R. China
}

new era of information, electronic, networked, and large numbers.

In July 1999, the China Geological Survey chose the Meishan section distribution area of Changxing, Zhejiang, as one of the first series of new national mapping projects. The projects have had an impact on the basic geological mapping of stratotypic sections and are significant at home and abroad. The Meishan Township sheet is the first candidate section of the international Changxing Stage standard section and the International Permian-Triassic Boundary Stratotype Section. That is, it is a support map of the global stratotype section and point (GSSP; commonly read as "Golden Spike") and is characterized by high-resolution, high-precision stratigraphic units (e.g., fossil zone, isochronous event stratum, high-frequency cycle stratum, boundary stratum) and integrated stratigraphy (Fig. 5.1).

This map comprehensively analyzes the special geological and geomorphological features of the Qinghai-Tibet Plateau unit in the context of the global tectonic pattern. In addition, it highlights recent achievements and insights of geological surveys and other scientific research. It also showcases outstanding achievements in regional geological surveys of and geological research in this area. As such, the map represents a new level of expertise achieved by Chinese geologists. Additionally, it represents the best map for international geologists seeking a comprehensive, objective, and detailed understanding of the general geological picture of the Qinghai-Tibet Plateau as well as the composition, structure, and evolution of each orogenic belt (Fig. 5.2).

This map was designated a pilot digital geological map for western China by the China Geological Survey (October 2001). This pilot project at a scale of 1:250,000 established and improved the current technical requirements for digital mapping using an entire sheet at the same scale. In addition, it provided information and a foundation for teaching digital geologic mapping, the development of software and hardware for a computer-assisted field mapping system and international exchange (Fig. 5.3). 


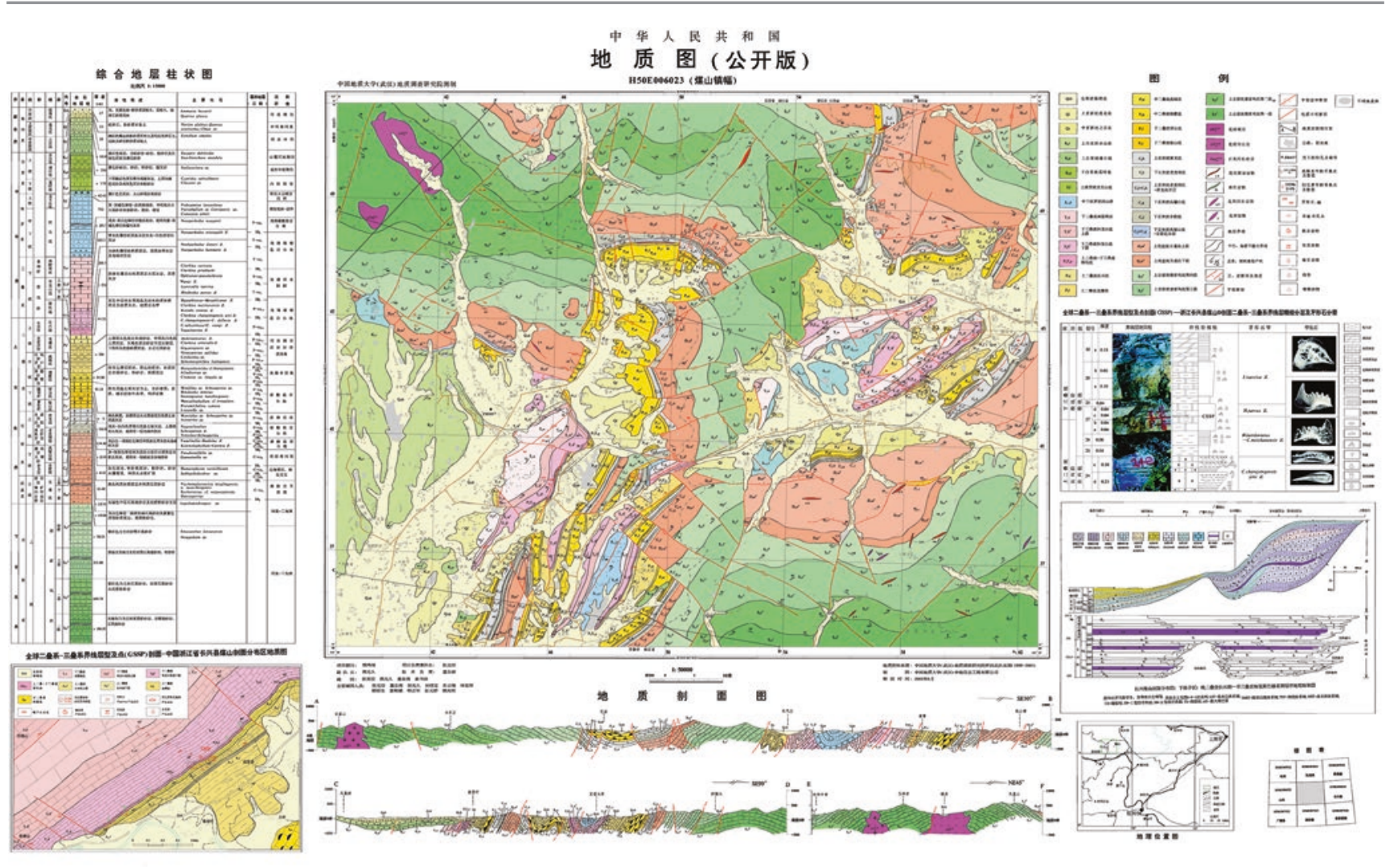

Fig. 5.1 Geological map of the People's Republic of China (H50E006023 Meishan Township sheet) [1]

This map is the first to fully describe the Asian continent and adjacent waters. In addition, it is the first Asian geological map with a spatial database, thus representing a significant advance toward the digitalization of Asian geol- ogy. It is also the latest, most comprehensive international geological map of Asia and has been recognized as a masterpiece and a milestone in the history of Asian geoscience research (Fig. 5.14). 


\section{青藏高原及邻区地质图}

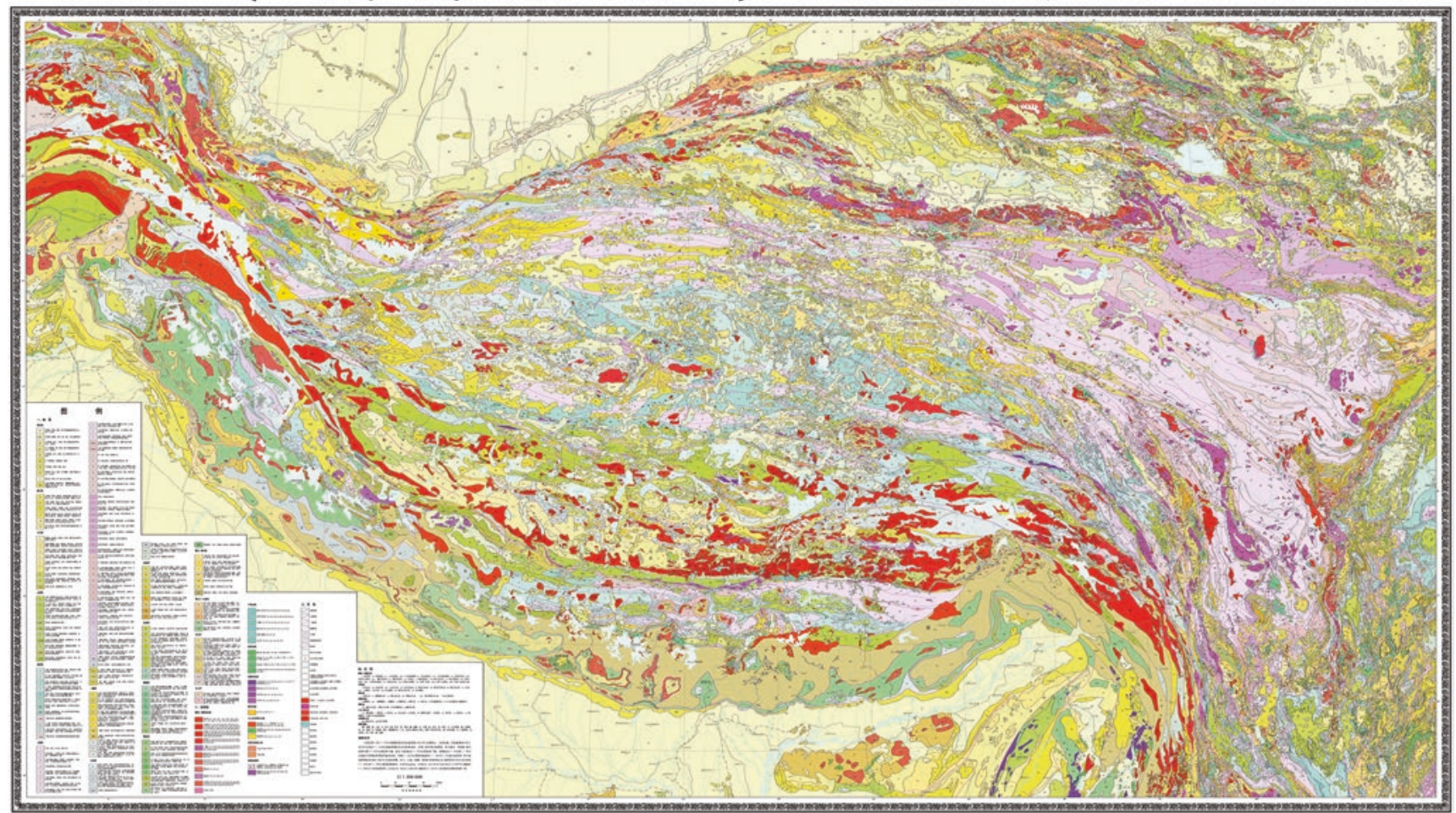

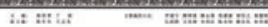

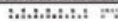

Fig. 5.2 Geological map of the Qinghai-Tibet Plateau and adjacent areas $(1: 1,500,000)$ [2] 


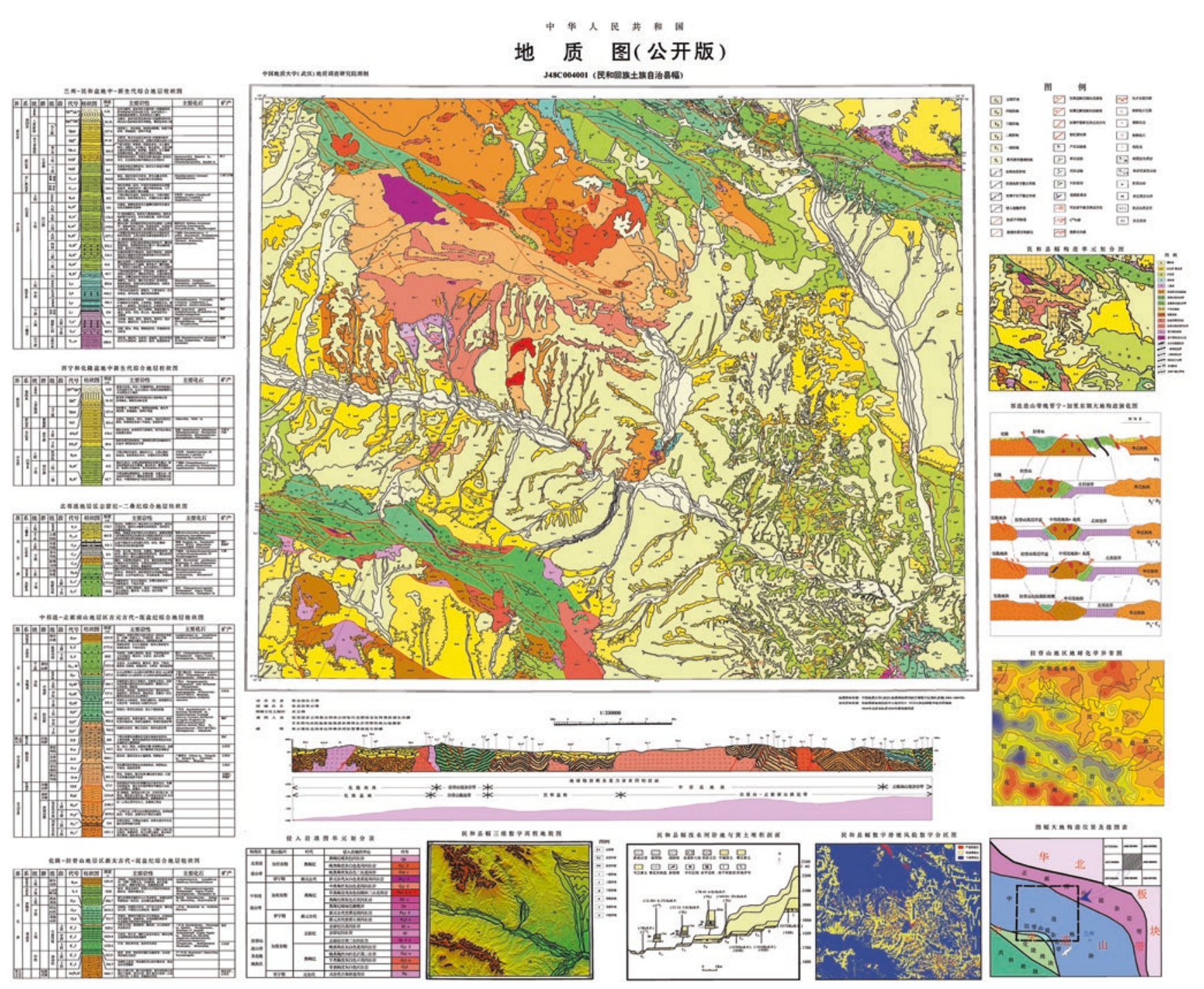

Fig. 5.3 Geological map of the People's Republic of China (J48C004001 Minhe Hui-Tu Autonomous County sheet) [3] 
新疆库尔勒兴地塔格地区铜镍成矿带化探普查区

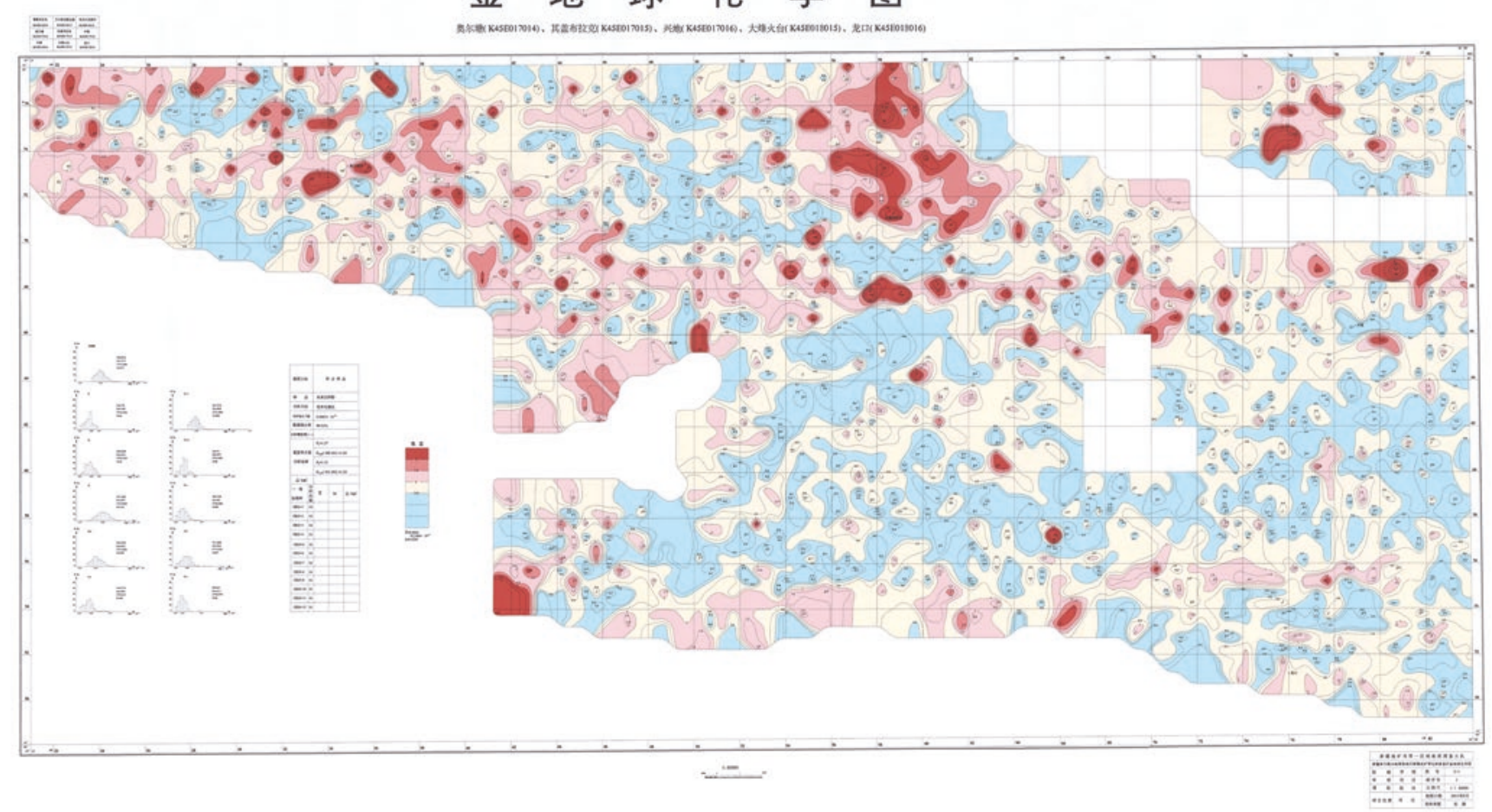

Fig. 5.4 Geochemical map of gold deposits in the general chemical prospecting area of the copper-nickel metallogenic belt in Taga and Korla, Xinjiang [4] 


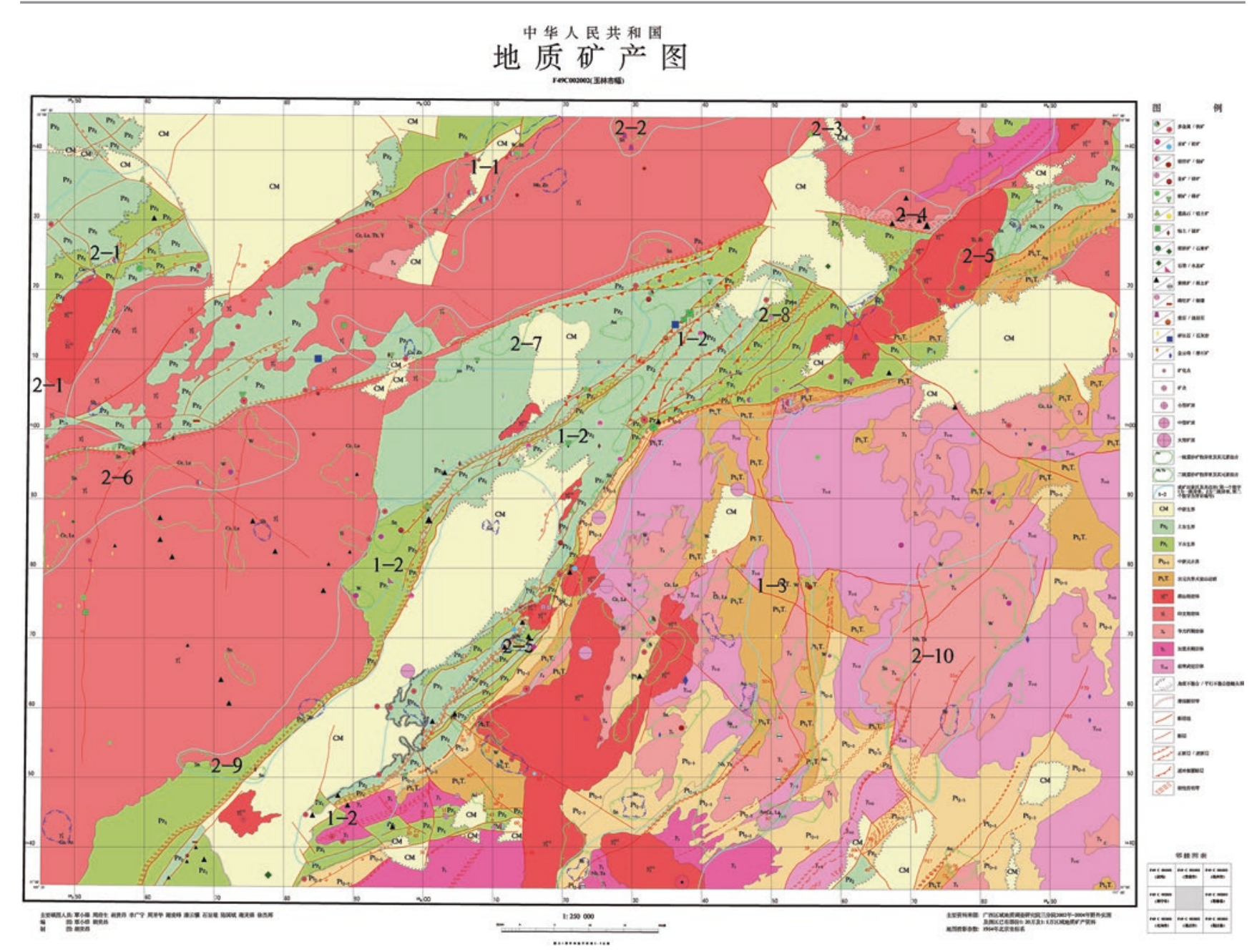

Fig. 5.5 Geological mineral map of the People's Republic of China (Yulin City sheet) [5] 


\section{卫片影像解秚地质图}

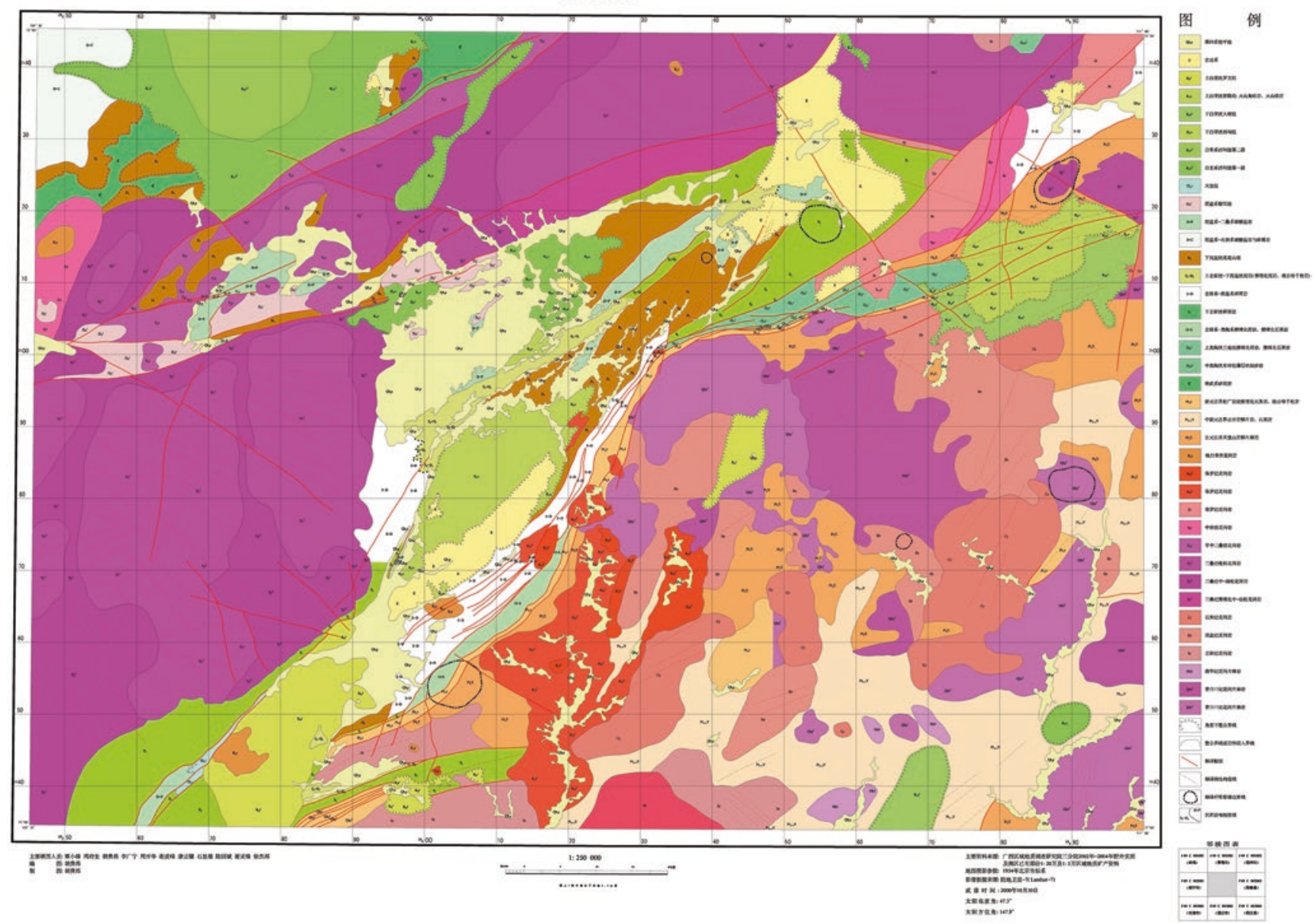

Fig. 5.6 Geological map based on a photogrammetric interpretation of satellite imagery of the People's Republic of China (Yulin City sheet) [6] 
中华人民共和国

数字旅游资源分布图

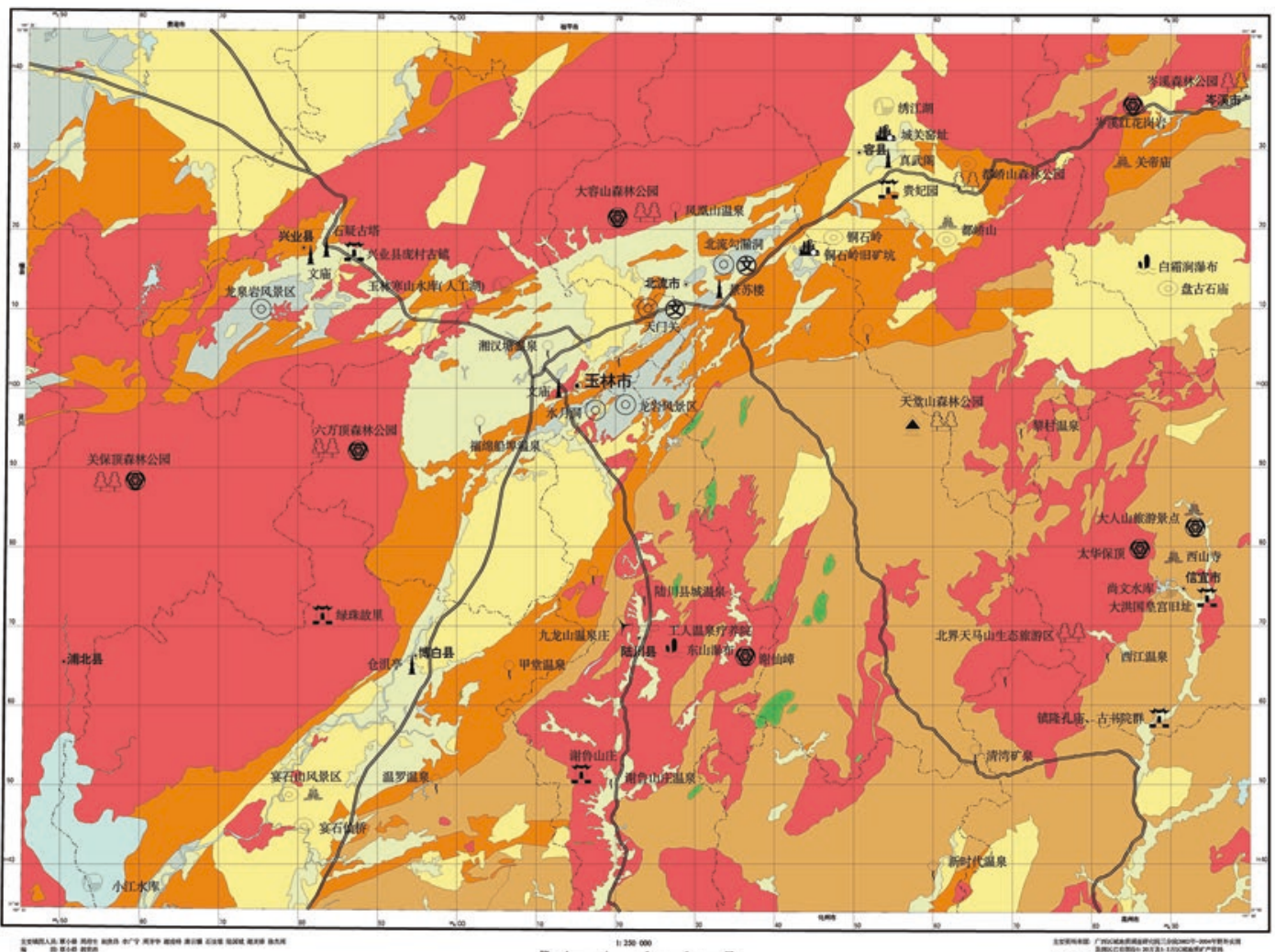

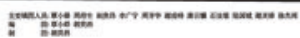
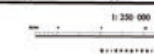

图例

一、景观类型图例

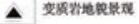

of 隹住

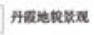

I. 古建筑

1 古埗

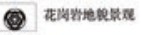

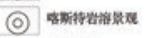

(ख) Bjiten

ㅈ. 名人教居

1 wa

(19) 人工时

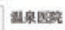

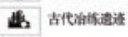

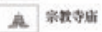

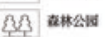

? 릴ㅊ

二、背景图例

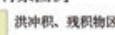

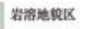

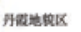

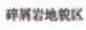

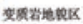

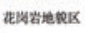

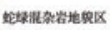

样. 酒洨

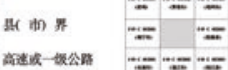

Fig. 5.7 Digital tourism resources distribution map of the People's Republic of China (Yulin City sheet) [7] 
中华人尼共和国

数字地震震中分布图( 公开版)

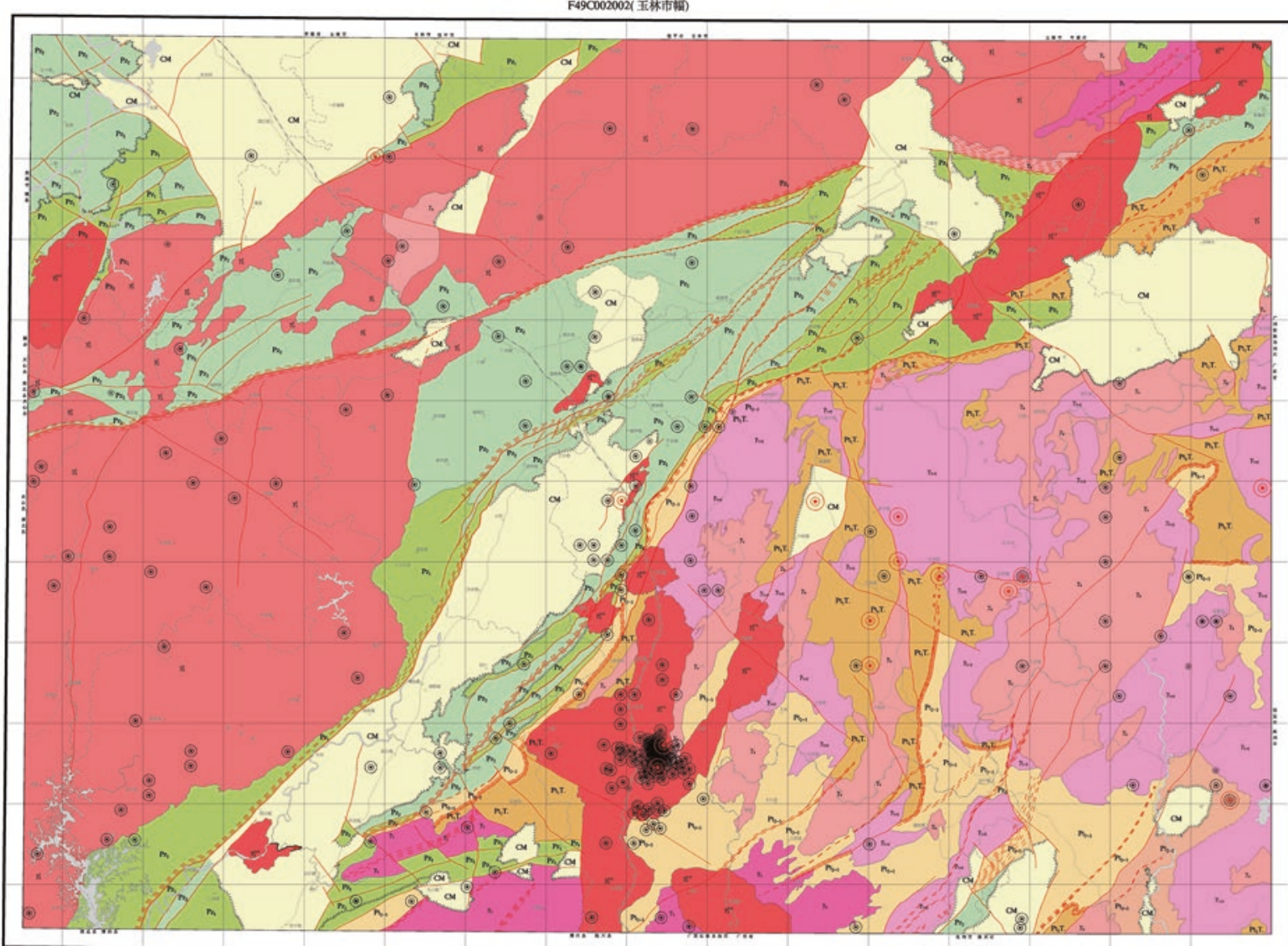

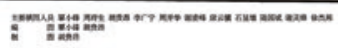

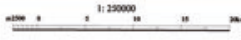

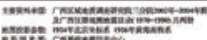

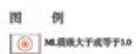

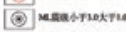

- venastatio

(4) +ะบn

mis Exen

m Fas

mint weats

[n工 Bxanxoum

질

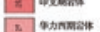

5 muknak

1.

$\square_{\text {naxemat }}$

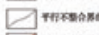

$\triangle$ somen:

$\square_{\text {reximu }}$

$A_{100}$

F.

7 marnomionera

Fan

可

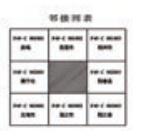

Fig. 5.8 Digital earthquake epicenter distribution map of the People's Republic of China (Yulin City sheet) [8] 
中华人民共和国

数字植被及农作物分布图

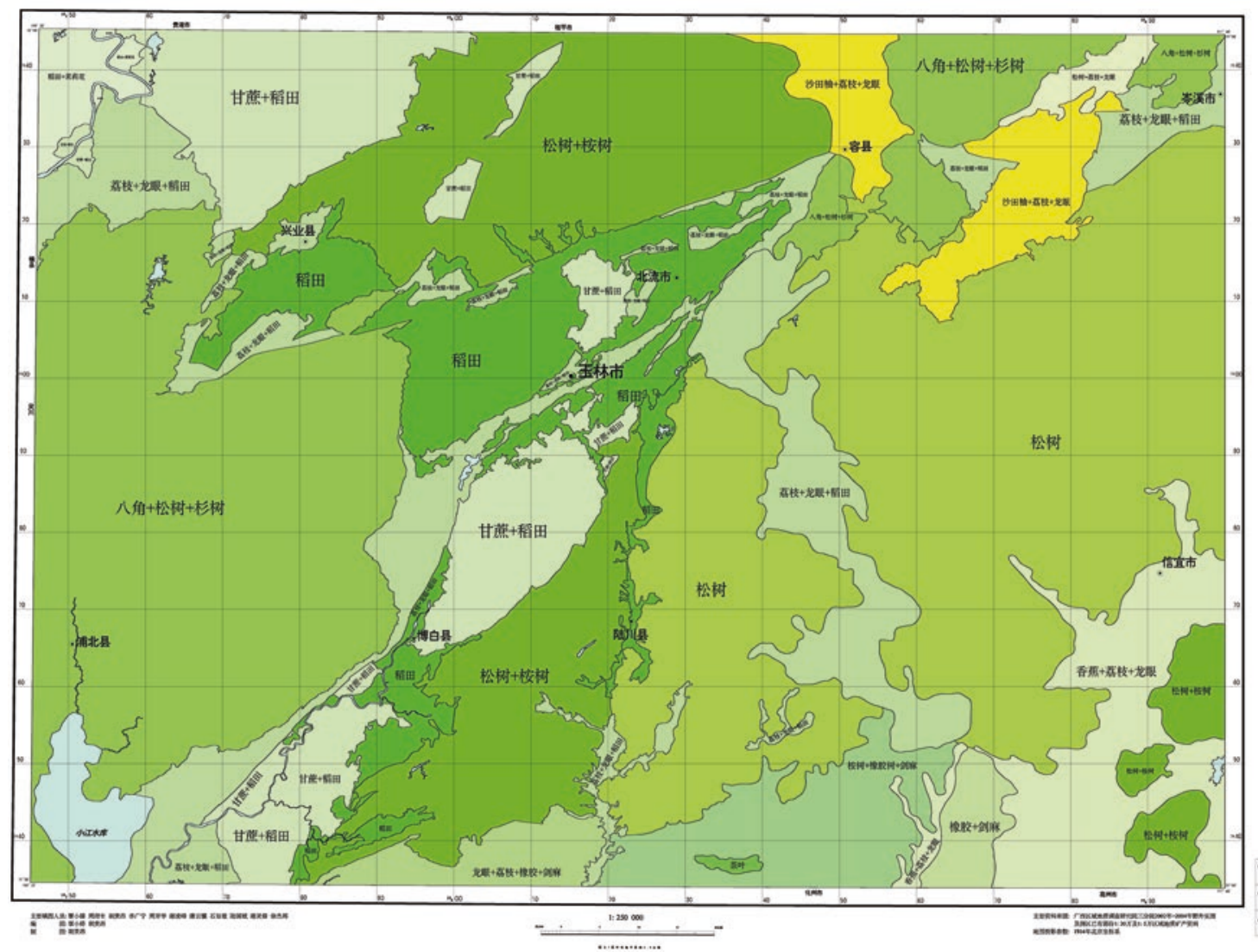

图例

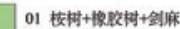

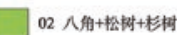

03 茶叶

04 嘴田

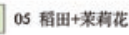

06 甘萠+榴田

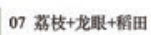

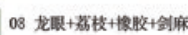

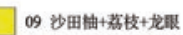

10 松时

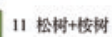

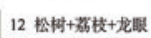

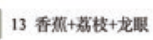

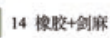

15 水革

Fig. 5.9 Digital vegetation and crop distribution map of the People's Republic of China (Yulin City sheet) [9] 
Fig. 5.10 Geophysical integrated anomaly map of the No. 23 Line for general prospecting of the copper polymetallic deposit south of Kenshan, Xin Barag Right Banner, Inner Mongolia [10]

\section{附图12 内蒙古新巴尔虎右旗垦山南铜多金属矿普查} 23 线物探综合异常图

Om $100 \mathrm{~m} \quad 200 \mathrm{~m}$
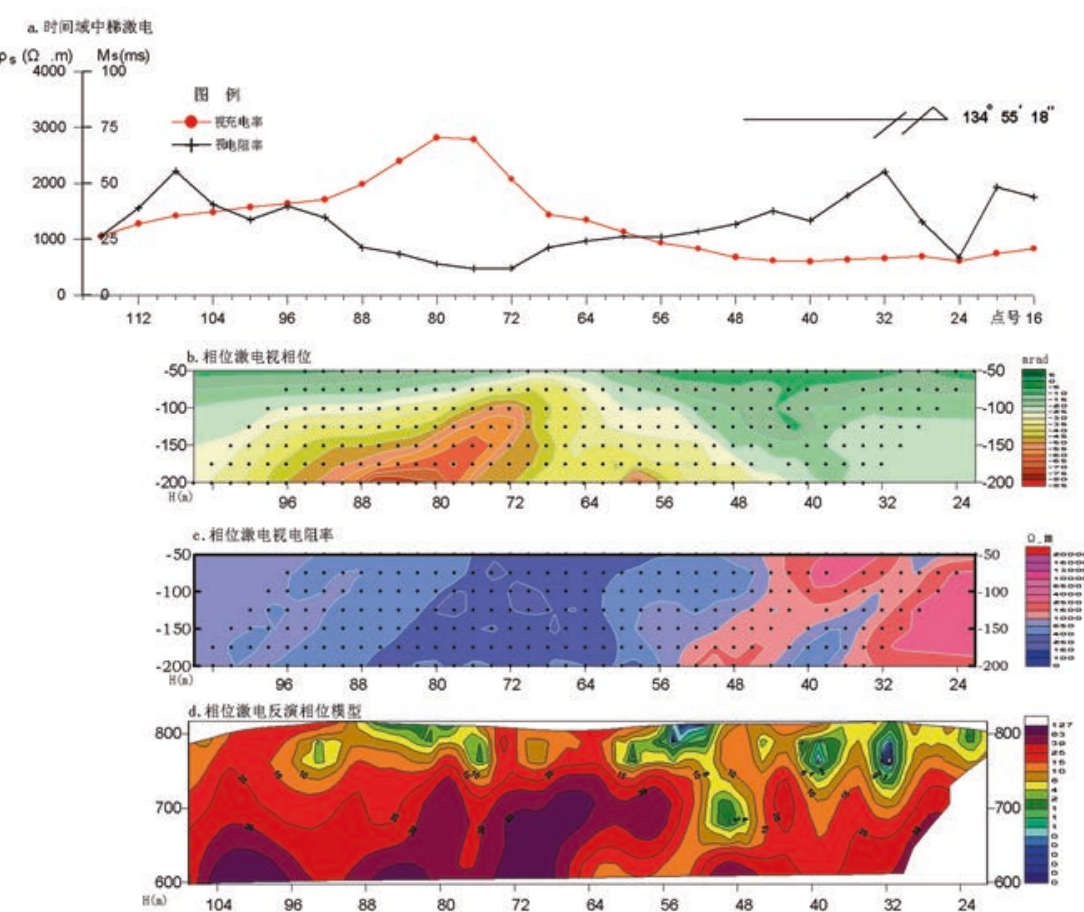

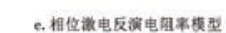

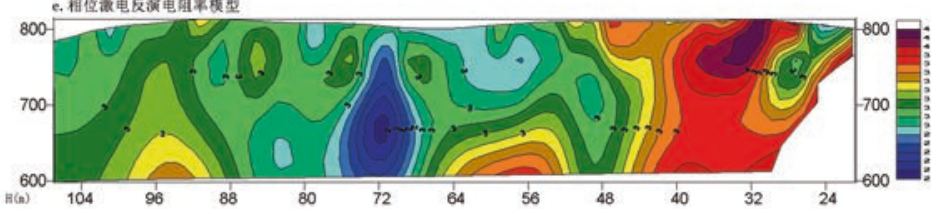

f. CSAMT反演电阻率

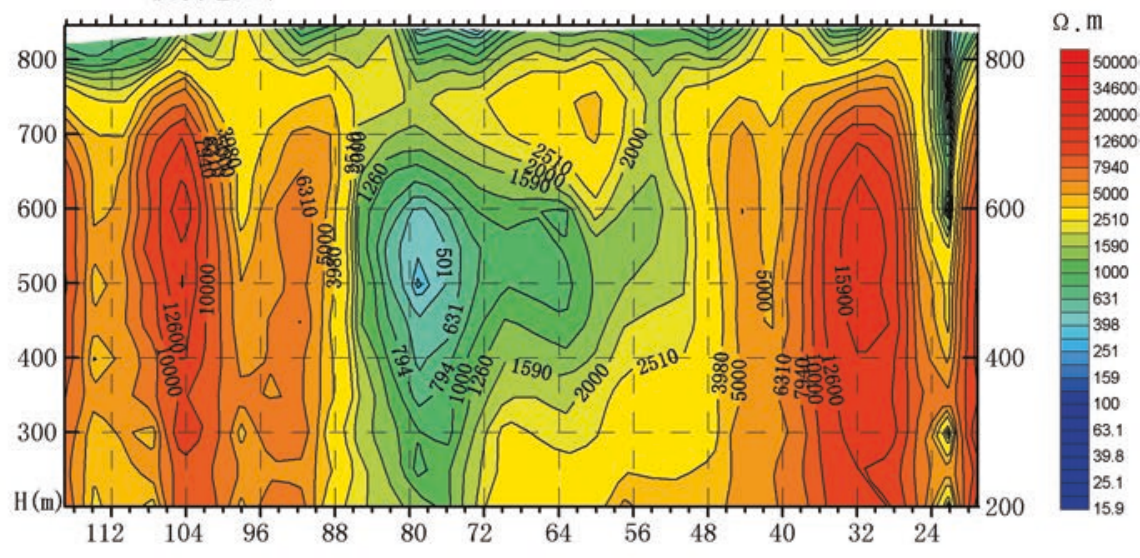

中国地质科学院物化探研究所

内蒙古新巴尔虎右旗蒝山南铜多金属矿普查 23线物探综合异常图

\begin{tabular}{|lr|l|l|c|}
\hline 编 & 图 & 刘瑞德 & 比例尺 & $1: 10000$ \\
\hline 审 & 核 & 黄力军 & 日 期 & 2006.11 \\
\hline \multicolumn{2}{l|}{ 项目负责 } & \multicolumn{1}{l|}{ 朱立新、黄力军、李宪臣 } \\
\hline
\end{tabular}




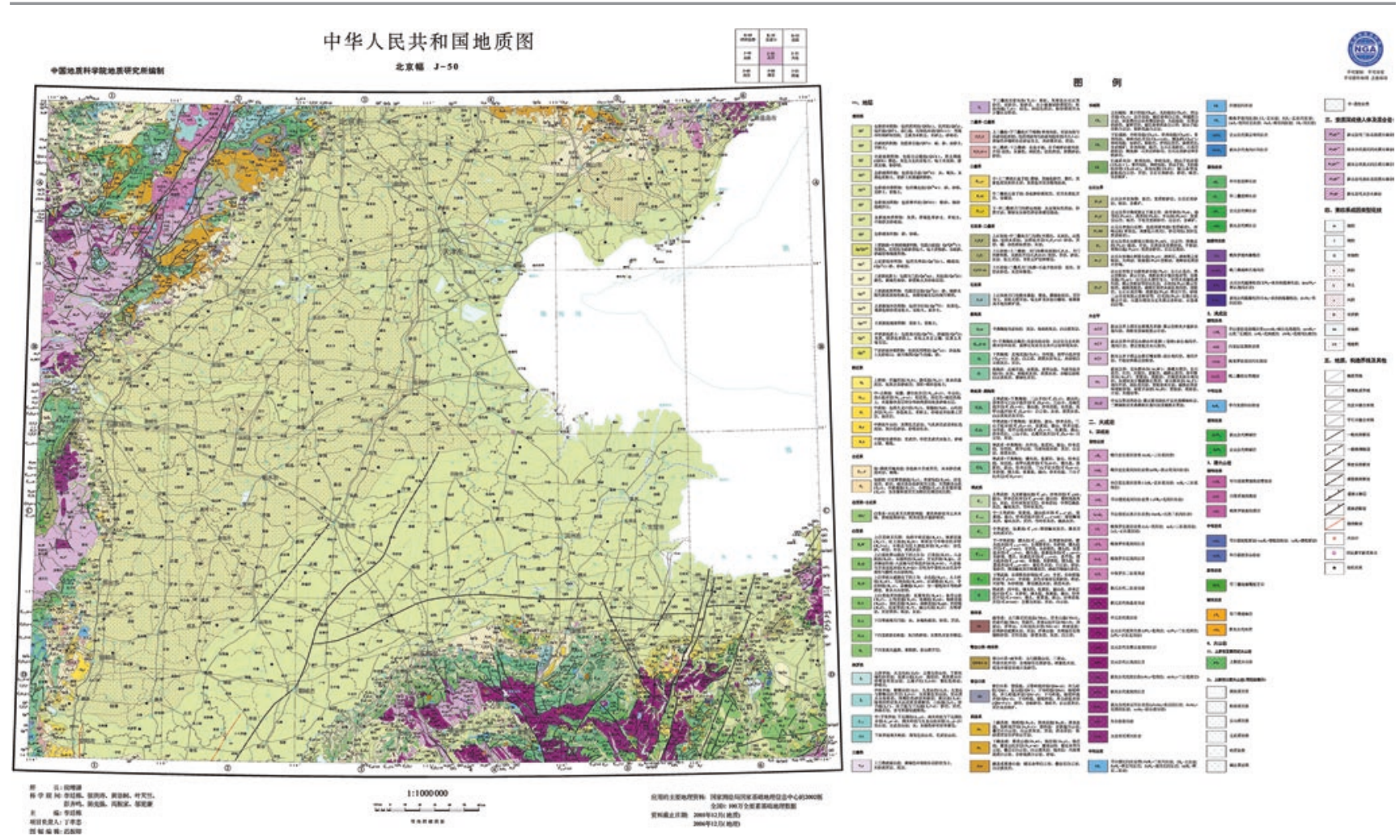

Fig. 5.11 Geological map of China (J-50 Beijing sheet, 1:1,000,000) [11] 


\section{喀依尔提河幅化探采样点分布图(公开版) \\ 新疆呼什托格斯地区 L 45E 002024(喀依尔提河幅)}
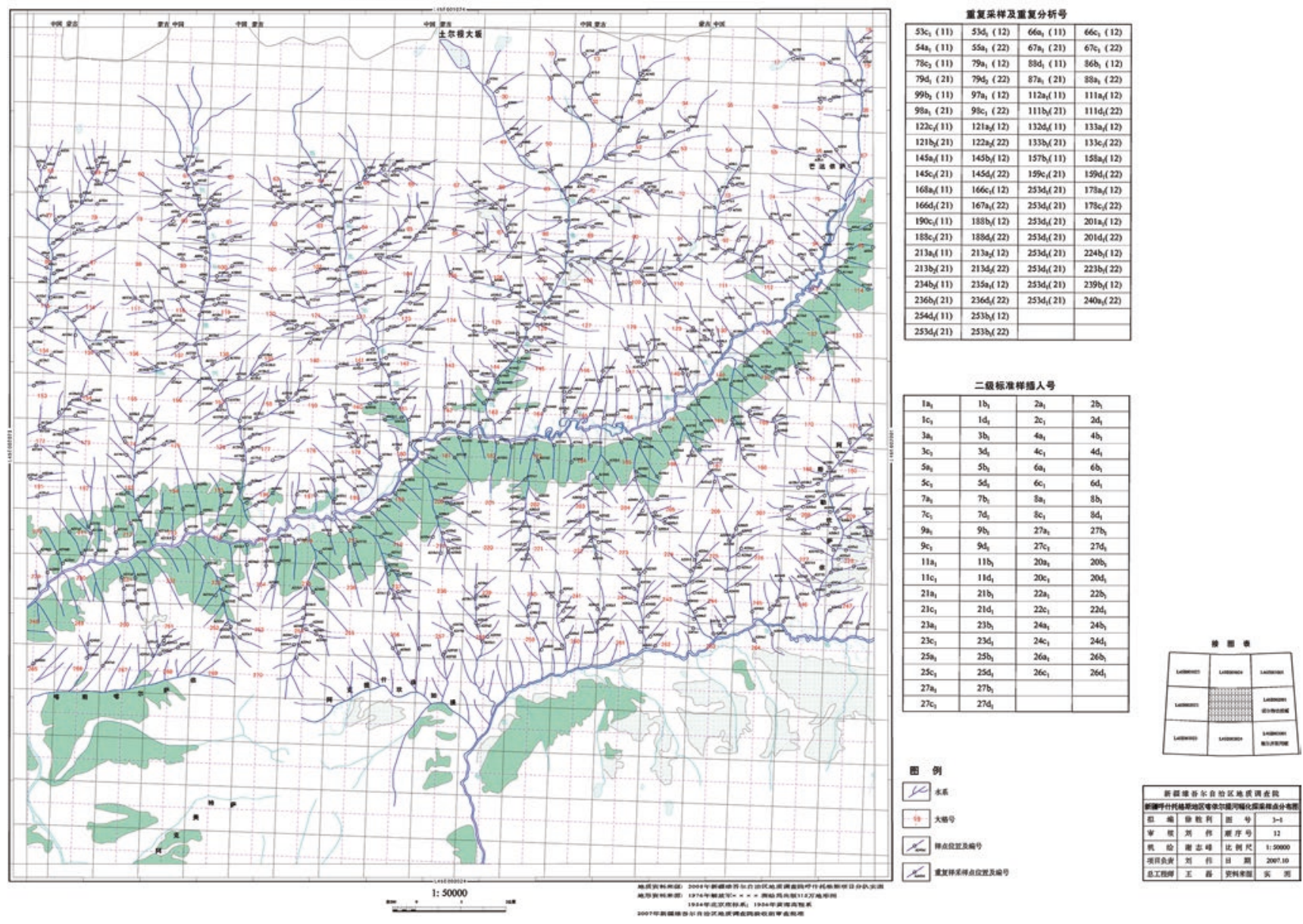

Fig. 5.12 Distribution map of geochemical exploration sites in the Kayilti River region, Hustogus District, Xinjiang [12] 


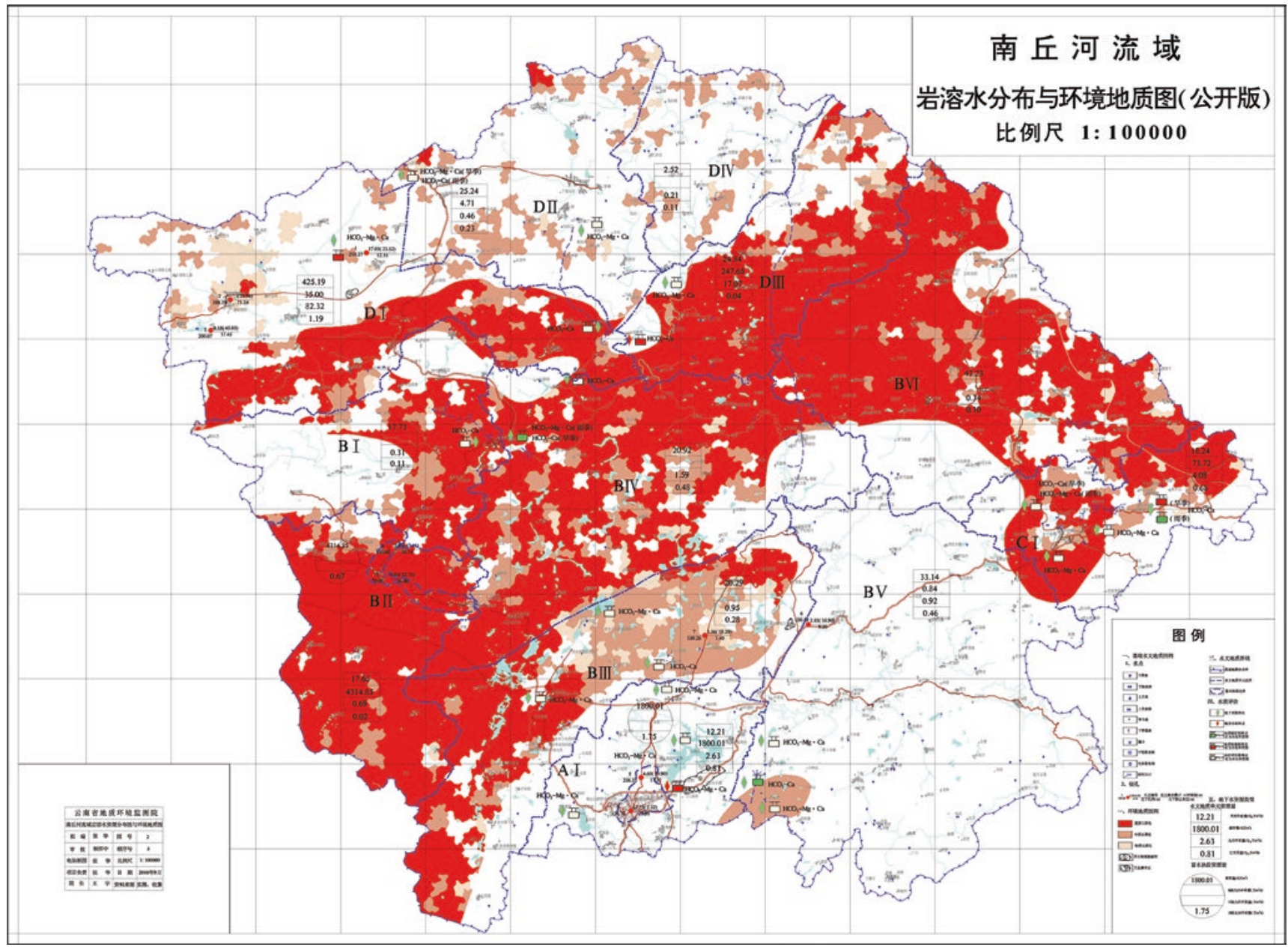

Fig. 5.13 Karst water distribution and an environmental geological map of the Nanqiu River Basin [13] 

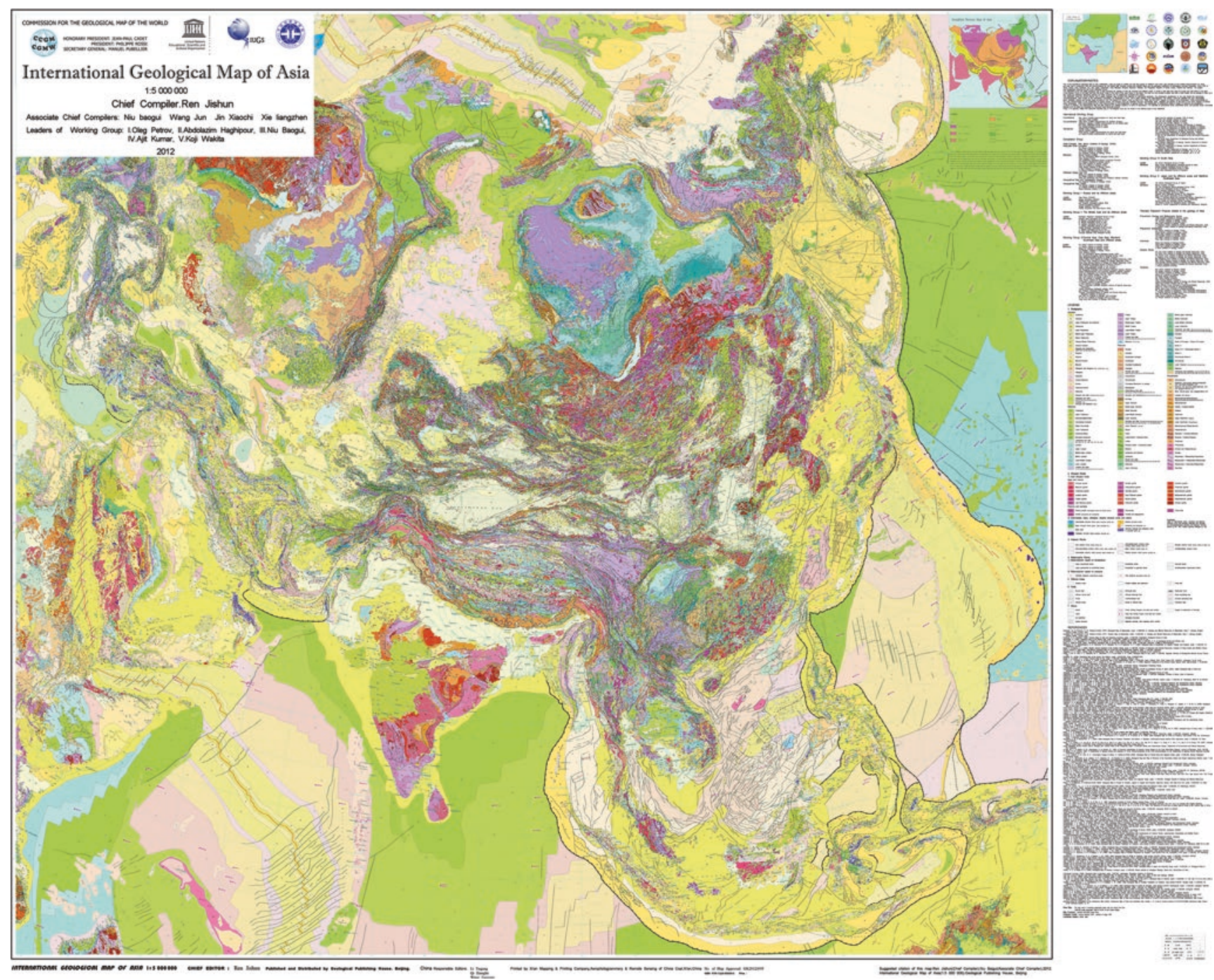

Fig. 5.14 International geological map of Asia (Scale: 1:5,000,000) [14] 


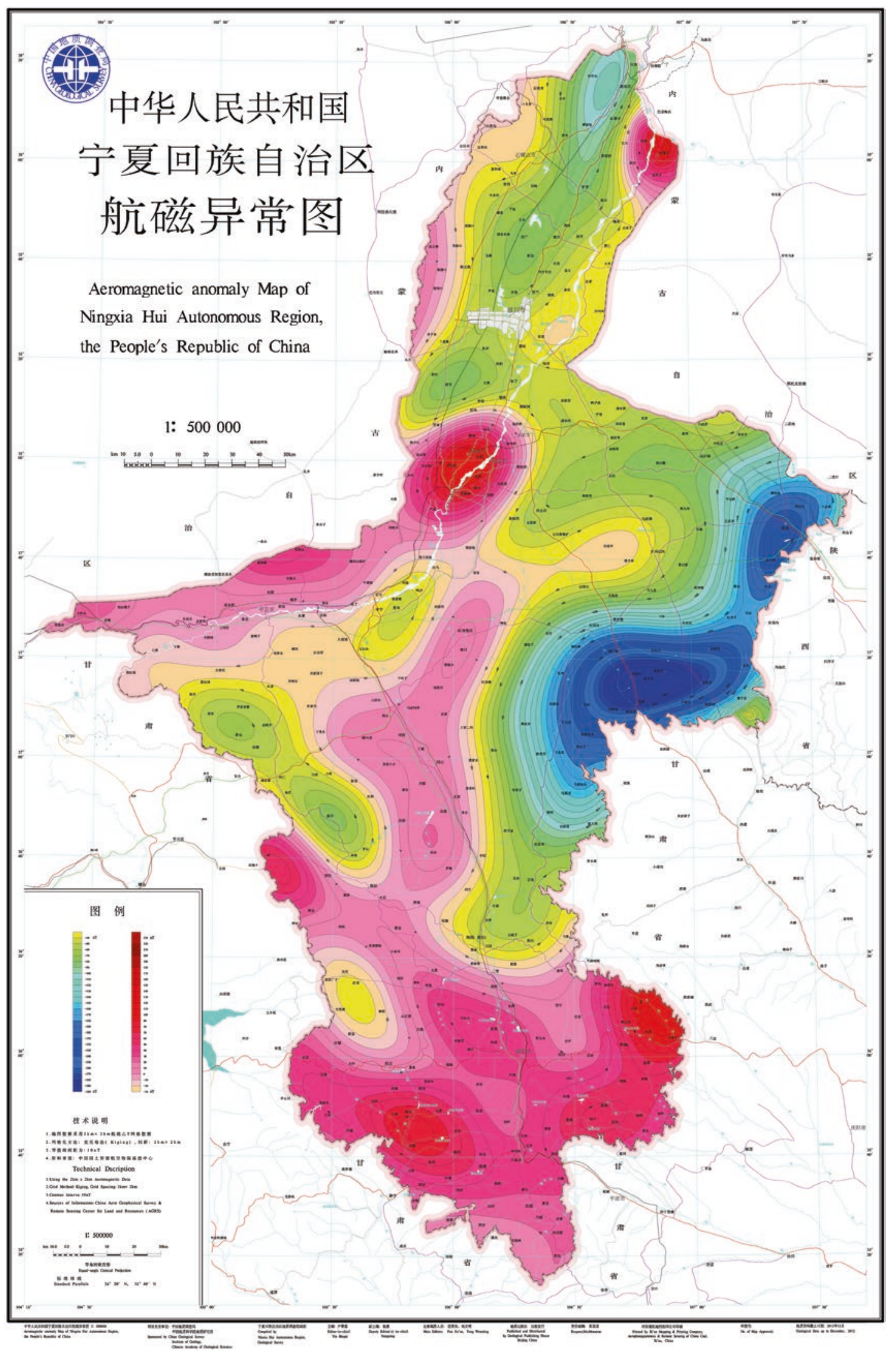

Fig. 5.15 Aeromagnetic anomaly map of Ningxia Hui Autonomous Region [15] 


\section{References}

1. Zhang Kexin, Hou Guangjiu, Tong Jinnan, Suo Shutian. Geological Map of the People's Republic of China (H50E006023 Meishan Township Sheet). 2002. doi: https://doi.org/10.12063/data.A.2018. NGA122598.T1.1.1.

2. Pan Guitang, Ding Jun, Yao Dongsheng, Wang Liquan, Luo Jianning, Yan Yangji, Yong Yongyuan, Zheng Jiankang, Liang Xinzhi, Qin Dehou, Jiang Xinsheng, Wang Quanhai, Li Rongshe, Geng Quanzhi, Liao Zhongli, Zhu Dicheng. Geological map of the Qinghai-Tibet Plateau and adjacent areas $(1: 1,500,000)$. Chengdu, Chengdu Map Publishing House, 2004.

3. Zhang Kexin, Zhu Yunhai, Lin Qixiang, Fan Guangming, Zhang Zhiyong, Gu Yansheng, Sun Ze. Geological Map of the People's Republic of China (J48C004001 Minhe Hui-Tu Autonomous County sheet). 2005. doi: https://doi.org/10.12063/data.A.2018. NGA122809.T1.1.1.

4. Zhao Jie. Geochemical map of gold deposits in the general chemical prospecting area of the Copper-Nickel Metallogenic Belt in Taga and Korla, Xinjiang. 2003. doi: https://doi.org/10.12063/ data.G.2018.NGA95374.T1.2.1.

5. Qing Xiaofeng, Hu Guiang. Geological Mineral Map of the People's Republic of China (Yulin City sheet). 2004. doi:https:// doi.org/10.12063/data.C.2018.NGA122581.T1.2.1.

6. Qing Xiaofeng, Hu Guiang. Geological map based on a photogrammetric interpretation of satellite imagery of the People's Republic of China (Yulin City sheet). 2004. doi:https://doi.org/10.12063/ data.F.2018.NGA122581.T1.3.1.
7. Qing Xiaofeng, Hu Guiang. Digital Tourism Resources Distribution Map of the People's Republic of China (Yulin City sheet). 2004. doi:https://doi.org/10.12063/data.Z.2018.NGA122581.T1.4.1.

8. Qing Xiaofeng, $\mathrm{Hu}$ Guiang. Digital Earthquake Epicenter Distribution Map of the People's Republic of China (Yulin City sheet). 2004. doi:https://doi.org/10.12063/data.F.2018. NGA122581.T1.5.1.

9. Qing Xiaofeng, Hu Guiang. Digital Vegetation and Crop Distribution Map of the People's Republic of China (Yulin City sheet). 2004. doi:https://doi.org/10.12063/data.Z.2018.NGA122581.T1.6.1.

10. Liu Ruide. Geophysical integrated anomaly map of the No. 23 Line for general prospecting of the copper polymetallic deposit south of Kenshan, Xin Barag Right Banner, Inner Mongolia. 2006. doi:https://doi.org/10.12063/data.F.2018.NGA123282.T1.12.1.

11. Li Tingdong, Ding Xiaozhong, Chi Zhenqin. Geological Map of China (J-50 Beijing sheet, 1:1,000,000). 2006. doi:https://doi. org/10.12063/data.A.2018.NGA108010.T1.1.1.

12. Xie Zhifeng. Distribution map of geochemical exploration sites in the Kayilti River region, Hustogus District, Xinjiang. 2007. doi:https://doi.org/10.12063/data.G.2018.NGA119040.T1.12.1.

13. Zhang Hua. Karst water distribution and an environmental geological map of the Nanqiu River Basin. 2010. doi:https://doi. org/10.12063/data.D.2018.NGA119772.T1.5.1.

14. Ren Jishun (Chief Compiler), Niu Baogui(Associate Chief Compiler). International Geological Map of Asia (1:5 000 000). Geological Publishing House, Beijing, 2012.

15. Fan Jinan, Yang Wenming. Aeromagnetic anomaly map of Ningxia Hui Autonomous Region. 2013. doi:https://doi.org/10.12063/ data.F.2018.NGA132163.T1.4.1.

Open Access This chapter is licensed under the terms of the Creative Commons Attribution 4.0 International License (http://creativecommons. org/licenses/by/4.0/), which permits use, sharing, adaptation, distribution and reproduction in any medium or format, as long as you give appropriate credit to the original author(s) and the source, provide a link to the Creative Commons licence and indicate if changes were made.

The images or other third party material in this chapter are included in the chapter's Creative Commons licence, unless indicated otherwise in a credit line to the material. If material is not included in the chapter's Creative Commons licence and your intended use is not permitted by statutory regulation or exceeds the permitted use, you will need to obtain permission directly from the copyright holder. 